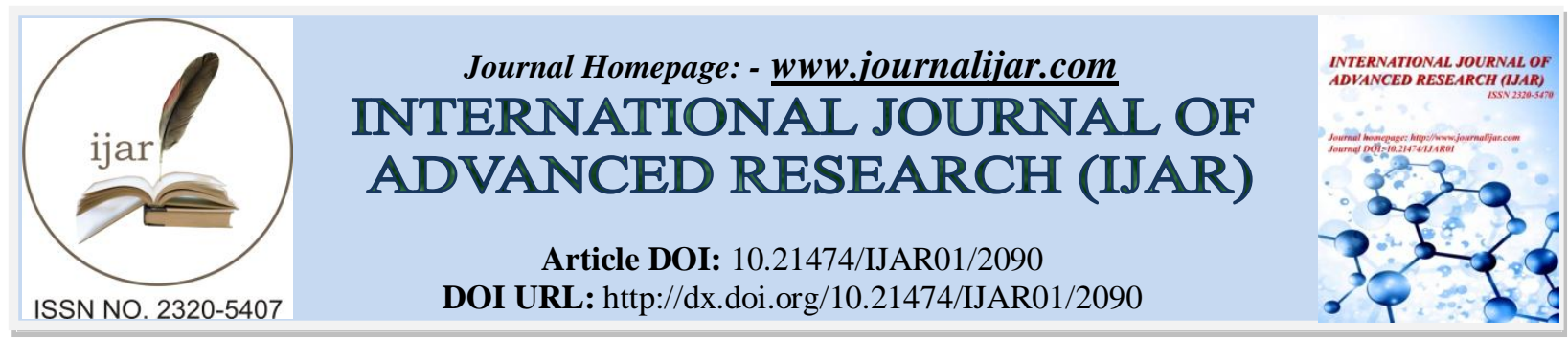

RESEARCH ARTICLE

\title{
RIBA (INTEREST) AS A CAUSE OF IMBALANCE SOCIETY AND ITS ISLAMIC PERSPECTIVE.
}

\author{
*Dr. Irfan Khalid.
}

Assistant Professor, Department of Islamic Studies, Federal Urdu University of Arts Science and Technology, Islamabad, Pakistan.

\section{Manuscript Info}

Manuscript History

Received: 24 September 2016

Final Accepted: 26 October 2016

Published: November 2016

Key words:-

economy, Riba, interest, usury, imbalance

\section{Abstract}

The prosperity and peace of a society much or less depends on its economy. While for the smooth running of both, there are several instructions in Islamic Shariah that allows what is right and forbids what is wrong. When we talk about financial issues, Islamic Shariah strictly condemns Riba. The question may arise why Islam prohibits Riba? While it was already in practice before the advent of Islam and still it is a part of different economic systems throughout the world. It is simply because Islam gives respect to human beings and condemns all the attempts that are harmful and disgraceful for humanity. Therefore, Riba is not only forbidden in Islam but economic experts are also in search of its substitute. Since borrowing on interest rate creates several issues including: less efficient allocation of resources, indebtedness, unemployment and economic instability. While in society it causes injustices, inequity, poverty and imbalance etc. In this paper we are discussing how Riba causes imbalance in the society and instead Riba what Islam demands from its followers.

Copy Right, IJAR, 2016,. All rights reserved.

\section{Introduction:-}

The word Riba 'رب' is an Arabic word which means to increase, grow, augment, educate (child), swell, mount up(1). The word is also used in Holy Quran in different meanings but when it appears in the verses based on financial matters then it means 'Interest' or 'Usury'(2). That's why the term Riba is used in this paper instead of the word 'interest' or 'usury'. Similarly, Shah Waliullah defines it as, 'a loan that lender provides to the borrower on the condition that he will return more or better than the loan(3).

Riba plays an important role in different economic systems but is prohibited in the Islamic Shariah (law). Islamic Shariah is based on the Holy Quran and Sunnah of the Prophet Muhammad (peace and blessings of Allah be upon him). One may become curious on this attempt of Islam that why Islam prohibits Riba? While it was already in practice before the advent of Islam and is also a part of different economic systems throughout the world. It is simply because being the 'standard religion'(4), Islam honors(5) the human beings and condemns all the attempts that are not beneficial for humanity. Riba is also one of them, as it causes several issues not only in the society but also affect its economy in the form of financial issues, money circulation, proper allocation of resources, injustices, poverty, indebtedness, unemployment, inequity and imbalance.

Corresponding Author:- Dr. Irfan Khalid.

Address:- Assistant Professor, Department of Islamic Studies, Federal Urdu University of Arts Science and Technology, Islamabad, Pakistan. 


\section{Riba as a Cause of Imbalance in the Society:-}

People may involve in Riba as borrower or lender and both of the situations create different issues in the society. Now the question may arises, if borrower gets profit then how it's problematic for society? Surely it seems to be profitable for the borrower; however, that is not in the long run of the society and its economy. Financing by borrowing at interest leads to different issues, such as: less efficient allocation of resources, economic instability and indebtedness of government, individuals or organizations(6). For example: only on household debt that is of $\$ 3$ trillion the US pays $\$ 300$ billion interest yearly(7).

As to promote Riba means to legalize the lenders that they may devour Riba without making any effort and definitely it will cause laziness and lethargy among them. Now the lenders will get this short cut for their future survival instead of investing their capital in any business that is based on profit and loss sharing, while no industrialization means increment in unemployment rate. Due to all these issues there will be no proper mechanism of money circulation in the society and many people will face money scarcity that may lead to the dismantling of social and humanitarian ties among different classes(8).

Another aspect of Riba as a cause of imbalance society becomes obvious when borrowing leads to loss. In this case the involvement in borrowing may be 'to fulfill basic needs' or 'for business purpose', if borrowing is to meet basic needs then it's extreme of brutality from the lender (whether it is an individual or organization etc.) to take interest from the poor. While if the borrower was financially established but involved in Riba to start or enhance business but suffered great loss in business then it will be difficult for borrower to return the loan and interest. Therefore, to provide Riba based loan means to facilitate borrowers in becoming a burden for the economy and society. Instead, there is a need to motivate financially established ones towards interest free loans or charity.

According to 'The Guardian' newspaper, "The vast and growing gap between rich and poor has been laid bare in a new Oxfam report showing that the 62 richest billionaires own as much wealth as the poorer half of the world's population."'(9) When there is already such a worst situation in the World that every night one in nine persons sleep hungry(10). Definitely, it would not be possible for them to make healthy relationships with other members of the society. Even it may cause enmities, cutoff and hatred among the members of a society(11).

About the cause of money scarcity Anthony Migchels writes: "American Populists always focused on scarcity of money. Expanding the money supply was their main goal, not Usury abolition. But Usury is the fundamental cause of money scarcity."(12) After highlighting this main issue of Riba, he further writes that "Usury is a constant drain on the money supply. Banks spend some of the interest back into the economy, but not all." (13) In this way, interest contributes in the economic enslavement not in the real development and affluence to the society(14).

\section{Islamic Shariah and Riba:-}

Islam is the religion for the betterment of humanity, it promotes goodness and condemns all that harm others that's why Riba is prohibited in Islamic Shariah. Instead Islam proposes a system of helping people without expecting anything in return(15) based on mutual trust not accusations(16). In order to serve humanity at its best there is a concept of lawful and unlawful in Islam and Riba is in the list of those which are strictly condemned by Almighty Allah. About Riba and its prohibition there are several instructions in Holy Quran and Ahadees (teachings of the Prophet Muhammad peace and blessings of Allah be upon him) that we are discussing here briefly:

\section{(a) Prohibition in Holy Quran:-}

There are different verses in the four chapters of Holy Quran regarding Riba. In the very first verse that was revealed in Makkah, there is a motivation to spend on charity instead of Riba, as it says that charity pleases Allah not Riba therefore Allah will only multiply charity(17). Then after the Prophet's migration to Madina the verse revealed was a step forward it orders the believers that do not devour Riba and fear Allah in order to get real success(18). Finally, Allah declared it prohibited and if anyone still involves in Riba based transactions then it's like a war with Almighty Allah and His Prophet (Muhammad, peace and blessings of Allah be upon him)(19).

Although the Holy Quran is a source of guide for all humanity but believers of the Holy Quran can gain maximum benefit from its teachings that's why by reminding them about the Day of Judgment Allay says that he who devour Riba will stand like the person who is insane by the touch of the Devil and it is due to their attempt against Allah's commandment that they consider Riba equal to the trade, while Allah had already prohibited Riba and permitted trade(20). 
The Holy Quran also indicates that Riba was also forbidden for Jews(21). However, the transactions were commonly Riba based in Arabia therefore for the ease of public, Islamic Shariah didn't ban it at once but it was made unlawful in several stages as mentioned above. The strategy was adopted not only for Riba's prohibition but also in some other issues just like intoxication(22). No doubt each and every thing that is prohibited by Islamic Shariah is for the amelioration of the humanity.

\section{(b) Prophetic Teachings about Riba:-}

The prohibition of Riba by Holy Quran is further explained by the Prophet Muhammad (peace and blessings of Allah be upon him). He practically implemented it by saying that all Riba is eradicated however people will get their capital then he waived all the Riba of his uncle, Abbas bin Abdul Muttalib(23). He motivated his companions to move at charity instead of Riba as there is no blessing in it(24) and cursed all those who either devour Riba, pay it, witness or record it(25).

The Prophet Muhammad (Peace and blessings of Allah be upon him) included Riba in the list of seven major sins that leads to the Hell(26). Even the Prophet's agreement with the Christians of Najran was based on the stipulation that they will not devour Riba(27). The same teachings were adopted by his companions in future, one of them is as follows:

A man gave loan to someone on the condition that he will return him better than it. Hearing this Abdullah Bin Umar said that it is Riba and explained the three types of loan: (i) a free loan that a person gives for Allah's pleasure. (ii) a free loan that a person gives to please his companion. (iii) a free loan that a person gives to return more than it. And the third one is Riba. Then the man asked Abdullah Bin Umar what should he do now? Abdullah Bin Umar suggested him to withdraw the agreement and if the borrower returns you equal to what you lent then accept it. If it is less than yours, accept it with a hope that Allah will recompense it. However, he may return you better than yours as gratitude and that will be your reward(28).

That's a brief view of Islamic Shariah on prohibition of Riba. Here we can see the strictness in the words of Holy Quran to avoid Riba, it is just because Almighty Allah demands people to create an economic system, free from all types of exploitations(29). There are also some narrations from the companion of the Prophet Muhammad (peace and blessings of Allah be upon him) showing that he returned more or better than what he had borrowed. But it doesn't fall in the category of Riba as it was not predefined but an unexpected increase as a sign of gratitude.

\section{Conclusion:-}

The Riba based economy creates imbalance society. The involvement of people in Riba based transactions, whether it is collectively or individually, cause great hurdle in money circulation. No society can ever be considered as a balanced society where the rich becomes richer and the poor, poorer. Likewise, it will be difficult to keep on the social values instead there will be injustice, oppression and usurping on the one hand while jealousy, hate and poverty on the other hand. Definitely, how it's possible for the people to create a healthy relationship with those who are the cause of their sufferings in different types of financial issues. Therefore, Islam condemns not only Riba but all those who involve in it to eliminate any form of exploitation. It demands its followers to promote charity for Allah's sake and better reward in the life hereafter.

\section{References:-}

1. Omar, A. M. (2010). The dictionary of the Holy Quran: Arabic words, English meanings with notes: classical Arabic dictionaries combined. Hockessin, Del: NOOR Foundation-International Inc. p.200

2. Baalbaki, R. (1995). Al-Mawrid A Modern Arabic-English Dictionary, 7th Ed., Beirut: Dar el-ilm Lilmalayin, p. 574

3. Ahmad, Shah Waliullah. (2005). Hujjat Ullah al-Baligha. $2^{\text {nd }}$ Ed. Beirut: Dar Al-Jail. p.164

4. Al-Quran 30:30

5. Al-Quran 15:30

6. Abdullah, A. K. (2013). The Pitfalls of Riba or Interest-Based Financing. ICR, 4(1), pp. 62-79. doi: $10.12816 / 000972$

7. Ibid

8. Al-Zahbi, M. (2003). Al-Kabair. $2^{\text {nd }}$ Ed. UAE: Maktaba Al-Furqan. p.151 
9. Larry Elliott. (2016, January 18). Richest 62 people as wealthy as half of world's population, says Oxfam. The Guardian. Retrived from https://www.theguardian.com

10. Ibid

11. Al-Zahbi, M. (2003). Op. cit.

12. Anthony Migchels - Real Currencies Oct 7, 2013 from https://realcurrencies.wordpress.com/2013/10/07/cause-and-effects-of-money-scarcity/)

13. Ibid

14. What is wrong with interest? Ansar Finance Group, Manchester

15. Saifee, A.R., Baloah, A.G., Khalid, I., Sultan, S. (2012). Islamic Strategies for the Elimination of Poverty from the Society. British Journal of Humanities and Social Sciences, 6 (1), 34-39

16. Tahir, A., Mahmood, A. K. (2015). Right to Honour and Repute in Islam. Ma'arif Research Journal. Issue 10. pp. 86-71 from http://mrjpk.com/right-of-honour-and-repute-in-islam/

17. Al-Quran 30:39

18. Al-Quran 3:130

19. Al-Quran 2:278-79

20. Al-Quran 2:275

21. Al-Quran 4:161

22. Al-Quran 5:90

23. As-Sibaa'ie, M. (2004). The Life of Prophet Muhammad Highlights and Lessons. (translated by Nasiruddin alKhattab) Riyadh: International Islamic Publishing House. p.180

24. Al-Qazvini, M. (n.d.). Sunan ibn Majah. The Chapters on Business Transactions. Vol. 3. Book 12. Hadith 2279

25. As-Sijistan, S. (n.d.). Sunan Abi Dawud. Book of Commercial Transaction. Book 22. Hadith 3327

26. Al-Nisai, A. (n.d.). Sunan an-Nisai. The Book of Wills. Vol. 4. Book 30. Hadith 3701

27. Al-Bilazari, A. (1987). Futuh-ul-Buldan. Beirut-Lebanon: Moassat-ul-Maarif. p. 86

28. Malik, I. (n.d.) Muwatta Malik. Book of Business Transactions. Book 31. Hadith 1379

29. Chapra, M. U. (1985). Towards a just monetary system. Leicester, UK: Islamic Foundation. p.63 